\title{
A Brief Assessment of the Main Commercial Contracts under The New Romanian Civil Code
}

\author{
Dan Velicu \\ Nicolae Titulescu University of Bucharest, Romania \\ dan.velicu@univnt.ro
}

VELICU, Dan. A Brief Assessment of the Main Commercial Contracts under the New Romanian Civil Code. International and Comparative Law Review, 2020, vol. 20 , no. 2, pp. 274-289. DOI: 10.2478/iclr-2020-0029

\begin{abstract}
Summary: From 2011 Romania has a new Civil Code. Although the government's initiative was to unify the private law according to the model of the Italian Civil Code of 1942 by repealing the Commercial Code of 1887 , the new Civil Code only succeeded in putting together civil rules and commercial rules, the latter being relocated from the former Commercial Code. Obviously, an exhaustive analysis of the new Civil Code is impossible in the frame of a short article. That's why the author of this study tries to evaluate the new Civil Code regulation by focusing on the main commercial contracts. Some general civil rules that are traditionally applied for centuries in most of the European continental legal systems (e.g. ownership concept, warranty for defects, the buyer's duty to pay the price etc) will be premeditatedly neglected or just shortly approached. The commercial contracts are very important in the field of the international commercial relations - even between the borders of the European Union - , when in many cases the parties agree that the national law will govern the contract. The goal of the study is to offer a brief commentary on the new institutions together with a comparative presentation of the general regulation of the main commercial agreements.
\end{abstract}

Keywords: sale agreement, mandate agreement, commission agreement, agency agreement

\section{Introduction}

On October 1, 2011 the new Civil Code came into force, being considered as a part of a comprehensive plan whose goal was to improve the administration of justice and to systematise the legislation following Romania's accession to the European Union.

The idea of a new Civil Code was not a new one. It generated debates since the interwar period, when famous academics and judges sustained that the private law which was grounded on the 1864 Civil Code - an improved copy of the 1804 French Code - and the 1887 Commercial Code - identical to the 1882 Italian one -, had to be adapted to social changes that took place in the Romanian 
society ${ }^{1}$. The academics were taking in account two paths of modernisation: first, a "conservative" one, that retained the traditional dualism - e.g. the Code Civil together with the Code de commerce, or the German Codes (BGB and HGB)-, and the second one, a "revolutionary" reform - promoted by Italian scholar Cesare Vivante - that unifies all the rules of the private law as did the Swiss Code des obligations. In 1938, a new commercial code was adopted, but it has never entered into force mainly due to the political turmoil and to some rules which were considered too "revolutionary". The debate did not cease and the adoption by fascist Italy in 1942 of the new Codice Civile could be an impulse that the second path be followed. Surprisingly, the 1864 Civil Code survived during the war and also during the socialist regime excepting the regulation regarding the family which became the object of the Family Code from 1954.

In the 1990s, it became obvious that the reformation of the 1887 commercial code was necessary, mainly because it had to provide a satisfactory regulation for the new commercial companies. Consequently, this regulation was repealed by the Law no. 31/1990, which is today the source of law regarding the companies' incorporation and the functioning.

Romania's accession to the European Union determined that many directives had to be integrated in the national legislation. This long process made the private law being atomized. The draft of the new code, which has undergone many changes since 2004 until now ${ }^{2}$, had, on the one hand, to harmonize the Romanian private law with European Union law and, on the other hand, to contain new rules created in the commercial practice or on jurisprudential ground. Consequently, the new Civil Code (NCC), which aimed to unify private law by replacing the two previous codes, implied the absorption of the commercial contract's regulation (Arts.60-76 and Arts.370-489 from the 1887 Commercial Code).

Surprisingly, even the authors of the Code claimed that having as inspirational sources the Codice Civile and the Code of Québec, the private law was finally unified, the leasing agreement was not retained in the Title IX of Book V - About obligations (Arts. 1650-2278 NCC) being until today regulated by a special law.

\section{Sale Agreement}

\subsection{A New Definition}

The sale agreement was one of the institutions that needed a new regulation ${ }^{3}$. On one hand, the new rules have to be retained in the frame of the contract and,

1 See DUMITRESCU, M.A. Manual de drept commercial. Bucharest: Alcalay, 1924, p. 18.

2 See VELICU, Dan. Il progetto di codice civile rumeno con particolare riferimento ai contratti. I Contratti, 2007, vol. 15 no.4, pp. 380-391, 381.

3 See e.g. Article 1582 from the French Civil Code. The French authors avoid actually to comment the article. See DELEBECQUE, Philippe, BINCTIN Nicolas, ANDREU, Lionel. 
on other hand the regulation and the key concepts must be compatible with the European regulation (e.g. the regulation of the consumer sales). Hence, according to the Article 1650 paragraph 1 NCC, the sale is an agreement by which the seller transfers or binds himself to transfer ownership of property to the buyer, for a price which the latter assumes to pay.

The definition is, in our opinion, deficient for it takes in account the hypothesis that the ownership can be transfer later and produce a confusion with the preliminary sale agreement. It is correct that the seller can agree to move into the future the moment of the ownership transfer, but this is an exception. Neither the Italian regulation, nor the Canadian one defined in this way. According to the Article 1470 "la vendita è il contratto che ha per oggetto il trasferimento della proprietà di una cosa o il trasferimento di un altro diritto verso il corrispettivo di un prezzo " while the Article 1708 from the Québec Code defines as follows : "La vente est le contrat par lequel une personne, le vendeur, transfère la propriété d'un bien à une autre personne, l'acheteur, moyennant un prix en argent que cette dernière s'oblige à payer". Both the definitions permit this exception ${ }^{4}$.

One explanation of this choice would be that the authors had also as model the definition from the proposals regarding the European regulation of sale agreement. However, these proposals tried to be compatible basically as possible with French and German regulation. On this path, they have to defined the sale agreement as a contract which enters into force immediately ${ }^{5}$ and the sale as two promises to transfer the ownership and to pay the price ${ }^{6}$.

However, the definition emphasized the ownership transfer and not the surrender of the goods as the French Code does.

If according to Article 1672 NCC the seller's main obligations are to transfer ownership, to deliver and to warrant the goods the buyer's obligations are accepting delivery of the thing purchased as typical duty and the payment of the price (Article 1719 NCC). Considering as essential obligation the take of the goods made feel the traces of $\$ 433$ para. 2 of $\mathrm{BGB}^{7}$, but also the Article 53 from the $\mathrm{CISG}^{8}$.

Opérations bancaires et Contrats commerciaux. Paris: LGDJ, 2018 pp. 333-471. We must add that even the definition offered by BGB was modified in 2001.

4 See BIANCA, Massimo. La vendita e la permuta.Torino: UTET, 1993, p. 93.

5 See Art.1583 from French Civil Code.

6 See $\$ 433$ of BGB.

7 See ECKERT, Hans Werner, MAIFELD, Jan, MATTHIESSEN, Michael. Handbuch des Kaufrechts. Munchen: CH Beck, 2007, p.1 et seq.

8 See Hof van Beroep 22 January 2007, Antwerpen, available at <http://www.unilex.info/ case.cfm?id=1314>, Tribunal de Commerce 12 March 2010, Versailles, available at $<$ http:// www.cisg.fr/decision.html?lang=fr\&date $=10-03-12>$. 


\subsection{The Sale of Someone Else's Goods}

Selling someone else's goods was a debatable subject under the 1864 Civil code'. Article 1599 from the Napoleonic Code forbidden it: "La vente de la chose d'autrui est nulle : elle peut donner lieu à des dommages-intérêts lorsque l'acheteur a ignoré que la chose fût à autrui". On one hand, the 1864 Civil Code did not reproduce the ban imposed by Article 1599 and, on the other hand the Commercial Code had not retained the provisions of Article 59 from the 1882 Italian Commercial Code which permitted it.

The new regulation, Article 1683 NCC recognize expressly the validity of the contract: the seller undertakes the duty to guarantee the ownership transfer from the real proprietor to the buyer. However, there is a difference. Article 1478 para.1 of the Italian Civil Code permitted any kind of sale: "Se al momento del contratto la cosa venduta non era di proprietà del venditore, questi è obbligato a procurarne l'acquisto al compratore". Article 1683 para.1 NCC refers only to determined individual goods.

Prima facie, the difference would not be so important. But, if we understand that the selling someone else's goods is a commercial institution rather a civil one, I think that was a good idea to regulate it and an error that the norm limited its application to determined individual goods.

The Italian code retains that the ownership is transferred to the seller only when the buyer became owner: "Il compratore diventa proprietario nel momento in cui il venditore acquista la proprietà dal titolare di essa".

Article 1683 NCC is more permissive. The seller's duty is considered to be executed, whether by the latter's acquisition of the goods, by the owner's ratification of the sale, or by any means, directly or indirectly, which provides the buyer the ownership of the goods.

Unless otherwise agreed, the ownership is transferred to the buyer from the moment of the acquisition of right by the seller, or when the sale agreement is ratified by the owner; the right is automatically and immediately transferred to the buyer under the consensus already expressed without any need for subsequent documents of translative nature.

If the seller does not transfer of ownership to the buyer in the above-mentioned ways, the latter may request the resolution of the contract, the reimbursement of the paid price, and, if necessary, damages.

9 ALEXANDRESCU, Dimitrie. Explicaţiunea teoretică şi practică a dreptului civil român în comparaţiune cu legile vechi şi cu principalele legislaţiuni străine. VIII. Bucharest: Socec, 1908, pp. 571-73. 


\subsection{Payment by Instalments}

Actually, paying the price by instalments became an usual type of conditional sale. The buyer can take and use the goods even he cannot pay the price at the moment when the contract is concluded. Consequently, the seller needs to be protected in the hypothesis when the buyer is insolvent.

Initially, the academics did not accept the retain of the ownership, but during the XX century the reservatio domini clause was accepted by the courts under the former 1864 Civil Code.

The 1942 Italian Civil Code and the BGB regulated this conditional sale agreement ${ }^{10}$. According to the art.1523 of the Codice civile "nella vendita a rate con riserva della proprietà, il compratore acquista la proprietà della cosa col pagamento dell'ultima rata di Prezzo ma assume i rischi dal momento della consegna". The transfer of the ownership occurs while the last instalment is paid, but the buyer assumes the risks when he is taking the goods. The $\$ 449$ (1) BGB states that "hat sich der Verkäufer einer beweglichen Sache das Eigentum bis zur Zahlung des Kaufpreises vorbehalten, so ist im Zweifel anzunehmen, dass das Eigentum unter der aufschiebenden Bedingung vollständiger Zahlung des Kaufpreises übertragen wird“.

On this path, Article 1684 NCC permit a clause by which the seller retains the ownership until full payment, even if the thing had been surrendered. Thus, retaining the ownership the seller manages to sell the goods when the lack of money would be an obstacle, and the buyer take and use the goods paying it by instalments.

Obviously, the reservatio domini clause may be opposed to third parties only after the publicity required by law has been completed.

With a different form, but a similar sense to that of Article 1523 of the Italian Civil Code, Article 1755 NCC provides that in a sale with value to be paid by instalments, if the payment obligation is guaranteed by maintaining the ownership, the buyer acquires the ownership at the moment when the final instalment is paid. As effect of law, the risk is transferred to the buyer from the moment of its delivery.

Unless otherwise agreed, the failure to pay a single rate, which is not higher than an eighth part of the price, does not entitle the seller to consider the contract terminated, and the buyer retains the period benefit for the successive rates (Article 1756 NCC).

In the event the seller has obtained the termination of the contract for failure to pay, he must repay all amounts received, retaining however, amongst other

10 See Articles $1523-1526$, and $\$ 449$ BGB. 
damages, and an equitable compensation for use of the goods by the buyer (Article 1757 NCC).

If it has been agreed that the amounts collected in respect of rates should be, in whole or in part, acquired by the seller, the court may nevertheless reduce these amounts, applying the appropriate provisions of the court regarding the reduction made by the court to the penal clause amount.

This rule is applicable both for the leasing contracts, as well as for the rental contract, if, in the latter case, it is agreed that upon termination of contract the ownership may be acquired by the lessee after the payment of the agreed amounts.

In international sales, all these provisions could have more relevance, because as stated Article 4 of CISG, the uniform rules are not concerned with the effect which the contract may have on the ownership transfer ${ }^{11}$. This basic principle had been early adopted by the courts ${ }^{12}$.

\subsection{A New Frame of the Delivery}

As it is well known the rules provided by the Napoleonic code referring to the delivery of the goods became anachronic ${ }^{13}$, because the regulation was conceived for sales between natural persons, and that philosophy made them a real obstacle in the commercial sale contracts where generally the goods are surrendered to the carrier. More, the buyer needs a lot of documents regarding the goods, documents that are related to their quality, origins, permissions to sell, and intellectual rights. In order to adapt it, Article 1685 NCC states that the delivery of the goods is carried out by placing the goods at the buyer's disposal together with all necessary in order to exercise possession.

Prima facie, the rule can be satisfactory for the commercial sale of goods. When movable things are sold, the delivery supposes handing the goods, the property title or any other documents or goods which permits the buyer at any moment to take possession of it (Article 1688 NCC). However, ignoring the handing over of documents as essential seller's obligation makes them deficient in regard to Article 30 of CISG ${ }^{14}$. Except when the parties have agreed otherwise, the seller has to deliver at the place where the goods were at the moment when the contract was concluded (Article 1689 NCC). This rule about the deliv-

11 See SCHLECHTRIEM, Peter, BUTLER, Petra. UN Law on International Sales: The UN Convention on the International Sale of Goods. Berlin and Heidelberg: Springer, 2009, p. 36.

12 See Oberlandesgericht Koblenz 16 January1992, available at <http://www.unilex.info/case. cfm? id $=30>$.

13 See Articles 1604-1606 from the French Civil Code.

14 See ENDERLEIN, Fritz, MASKOW, Dietrich. International Sales Law: United Nations Convention on Contracts for the International Sale of Goods: Convention on the Limitation Period in the International Sale of Goods. New York: Oceana, 1992, p. 138. 
ery place is very close or similar to that provided by the Article 31 (b) of CSIG ${ }^{15}$, but faced to the Article 31(c) of CISG, the new Romanian civil code fails to state a general rule in order to fix the place of delivery. More, unfortunately the new Romanian civil code does not regulate the case of delivery involving carriage of the goods, a hypothesis regulated by Article 31(a) of CISG and also by Article 1510 paragraph 2 of the Italian Civil Code. The latter is very clear: "Salvo patto o uso contrario, se la cosa venduta deve essere trasportata da un luogo all'altro, il venditore si libera dall'obbligo della consegna rimettendo la cosa al vettore o allo spedizioniere; le spese del trasporto sono a carico del compratore".

In case of the time of delivery, the Romanian regulation contains some special provisions. In a different way faced to Article 33 of CISG, which offers the seller three alternatives, Article 1693 NCC provides that if the parties didn't fix a specific date in order to deliver the goods, the buyer can require the delivery immediately after he has paid the price. However, if there are reasons - obviously known to the buyer when the contract was concluded - that do not permit an instant delivery, Article 1693 NCC presumes that the parties have agreed on carrying out the delivery later.

\subsection{The Warranty Mechanism}

Obviously, the guarantee for defects was preserved by the new regulation, and according to Article 1710 NCC, the buyer may request the termination of the agreement or the corresponding reduction of the price (remedy provided by Article 1355 from the old Civil Code and by Article 1644 from the Napoleonic Code). More, he can also request the removal of the defects by the seller at the latter's expense or the replacement of the sold goods with identical goods, but without defects. The regulation is similarly to $\$ 439$ paragraph 1 BGB which states that $\$ 439$ “der Käufer kann als Nacherfüllung nach seiner Wahl die Beseitigung des Mangels oder die Lieferung einer mangelfreien Sache verlangen”.

However, in order to consider the agreement terminated, similarly to the Article 39 CISG, the buyer must give notice to the seller specifying the nature of the defect within a reasonable time after he has discovered it (Article 1709 para. 1 ); when the buyer is a professional - new concept which substitutes the former merchant - and the goods is a movable and tangible thing, he must give notice within two day after he has discovered it (Article 1709 para. 2).

In order to offer more protection to the buyer, Article $1716 \mathrm{NCC}$ - similar to Article 1512 from the Italian Civil Code -, recognises an additional tool, a guarantee for the good functioning of the goods, generated by the will of the parties and not ex lege as in the case of a guarantee for defects. Therefore, if the seller has guaranteed for a specific period the proper functioning of the sold goods, he undertakes the commitment that, in case of any defect arising within the war-

15 See SCHLECHTRIEM, Peter, BUTLER, Petra. op. cit., pp. 6, 109. 
ranty period, he should repair the goods at his own expense. If the reparation is impossible, or if its duration exceeds the time agreed or by special law, the seller has to replace the sold goods. This remedy is also found in the regulation provided by the Directive 1999/44/CE of the European Parliament and Council regarding certain aspects of the sale of consumer goods and associated guarantees.

When there is no term provided by contract or by special law, the seller must repair the goods within 15 days. However, we must retain that the reduction of the price is not possible as in the case of the guarantee for defects. If the seller does not replace the goods within a reasonable period, at the buyer's request, he has to reimburse the price received.

Obviously, the defect can appear as a consequence of the buyer action, and in that case the warranty is excluded. Thus, the guarantee will have no effects when the seller proves that the defect occurred because of the inappropriate manner in which the buyer has used or kept the goods. The buyer's behaviour is considered by taking into account the written instructions which were communicated to him by the seller.

In order to use his rights which implies the warranty, the buyer must notice the defect before the expiration of warranty. If this notice could not be made within the guarantee period, for objective reasons, the buyer has to notice the defect within a reasonable period after the warranty's expiration.

These rules are applicable also when the seller has guaranteed that the sold goods will maintain certain qualities for a determined period.

Faced to the traditional guarantee for defects, in this case it would be sufficient for the buyer to prove that the initial goals were not achieved through the use of the goods, although it worked. In other words, the poor functioning of the sold goods does not implicitly imply the existence of a defect that might cause this.

\subsection{The Special Commercial Rules}

Regarding the "commercial sale contract" - which was regulated previously by Articles 60-73 from the Commercial Code -, we must add that the remedies for non-performance are settled actually by Article 1726 NCC. The seller is entitled to depose the goods in a warehouse, according to the first paragraph which is similar to Article 1514 from the Italian Civil Code ${ }^{16}$ and to $\$ 373$ paragraph 1 HGB - or to sell on current price or by auction, according to the second paragraph - which is similar to Article 1515 from the Italian Civil Code and to $\$ 373$ paragraph 2 and $3 \mathrm{HGB}^{17}$.

16 See more about these remedies BIANCA, Massimo. La vendita e la permuta. Turin: UTET, 1993, pp. 1087-1109.

17 See also ECKERT, Hans Werner, MAIFELD, Jan, MATTHIESSEN, Michael. Handbuch des Kaufrechts. Munchen: CH Beck, 2007, p. 429. 
According to the third and fourth paragraph of Article 1726 NCC, the buyer is entitled to buy the goods from other seller when the first seller didn't deliver the goods and this has a current price on local market. This rule is similar to Article 1516 from the Italian Civil Code.

When the goods is sold or purchased again, the seller or the buyer are entitled to receive the difference - if there is any - between the agreed price and the price obtained, and also damages.

\section{Supply Agreement}

The supply contract is one of the new specific contracts regulated by the new Civil Code, contract which is frequently used in commerce.

We find also in the case of this regulation the influence of the Italian Civil Code. Article 1559 from the Italian Civil Code provide the following definition: "La somministrazione è il contratto con il quale una partesi obbliga, verso corrispettivo di un prezzo, a eseguire, a favore dell'altra, prestazioni periodiche o continuative di cose"18. Article 1766 NCC is close to the notion of somministrazione.

In some words, by this agreement, one party - called the supplier - undertakes to transfer ownership of a given quantity of goods and deliver them, on one or more terms, subsequent to the contract or continuously, or to provide certain services, at one or more terms subsequent or continuously, and the other party - called the beneficiary - undertakes to take the goods or to receive services and pay their price.

The Romanian legislator (probably in order to emphasize the autonomous nature of the contract) stated as the esential obligation of the supplier the transfer of the title over the goods or the provision of services, unlike the Italian legislator, which in a more concise manner uses only the expression "prestazioni periodiche".

Article 1771 NCC provides the completion of the supply contract regulation with the provisions regarding the sale contract - which make us think that the supply is as sale version -, and Article 1766 paragraph 3 NCC, qualifies the contract grounding on the characteristic obligation ${ }^{19}$ that means the agreement could be also a service contract.

An useless rule, in our opinion, is found in the content of Article 1767 paragraph 1 NCC whose text provides that the transfer of ownership operates when generic goods are delivered, for Article 1678 NCC is applicable in this situation, and that article states that in the case of such goods the ownership transfer is determined by delivery.

18 See COTTINO, Gastone. Del contratto estimatario della somministrazione. Bologna : Zanichelli, 1970, p. 406 et seq.

19 See Art. 1570 from the Italian Civil Code. 
On the other hand, Article 1767 paragraph 2 NCC states that the reception of goods is made by the beneficiary, an occasion upon which their quantity and quality are identified and determined, provision which miss in the Italian regulation. The text is, in our opinion, unnecessary and confusing, because, on the one hand, according to Article 1678 NCC, in order to achieve the individualisation of goods it is necessary to count or weigh them, and the buyer has the obligation, according to Article 1690 paragraphs 2 and 3 NCC, to check the state of the goods upon reception and to immediately notify the case of any perceptible defects.

A set of rules regarding the amount of the purchase price are found in the content of Article 1768 NCC. Beyond the unnecessary provisions of the first paragraph, which states that the price is agreed by contract or by law, Article 1768 NCC establishes that in the case of supply contracts where the price is fixed by law (or by acts of the administrative authorities) the price or its determination mechanism originally agreed will apply, unless the law expressly provides otherwise.

When the law requires the price has to be paid including for the contracts in execution, either party may terminate the contract within 30 days from the entry into the force of the law.

Regarding the termination requirements of the contract, the provisions of general nature from Article 1277 NCC are applicable, and they are destined for all long term contracts according to which the unilateral termination can operate at the request of a party by observing a reasonable notice term; any contrary clause or the stipulation of a benefit in exchange for terminating the contract is considered without legal effects. Obviously, unilateral termination will have ex nunc legal effects.

Some express provisions were destined for outsourcing activities. Therefore, according to Article 1769 NCC, the provider may outsource the supply of goods or services to a third party, unless the contract has a personal nature or the essence of the contract does not allow this.

On the other hand, outsourcing shall be deemed to exist whenever the product or service covered by the supply contract is in fact provided, in whole or in part, by a third party with which the provider has outsourced to this purpose.

In both cases, the execution of the supply contract remains under the supervision of the supplier and the latter will respond to the beneficiary for the quality of the products or the services provided by the outsourcing third party, having the right to recourse against it (Article 1770 NCC). 


\section{Mandate and Commission Agreement}

Under the new code, the mandate and the commission agreement are regulated in a different manner. The definition of the mandate agreement (Article 2009 NCC) is only apparently similar to the old regulation, for Article 2011 NCC distinguishes between the mandate with representation and the one without representation ${ }^{20}$.

Consequently, in the system of the new Civil Code, the mandate with representation supposes drawing an empowerment, by which third parties will acknowledge the content of the legal relation between the principal and the agent, while the mandate without representation is a contract, according to which the agent executes legal documents in his own name, but on behalf of the principal, assuming to third parties the obligations resulting from these contracts, even if third parties had the knowledge about the mandate (Article 2039) ${ }^{21}$.

According to Article 2010 paragraph 1 NCC - and contrary to the sense of Article 1709 from the Italian Code and $\$ 662$ from BGB - a mandate concluded by and between two natural persons is presumed to be gratuitous, but a "professional" mandate is presumed to be onerous and that means the agent has the right to be paid. Remuneration, if any, is determined by the contract, usage or law or on the basis of the value of the services rendered.

More important for the international commercial relations is the commission agreement, governed by Article 2043 NCC. This is only a version of the mandate without representation, restricting its object to the purchase or sale of goods or perform services on the account of the principal and on behalf of the commissioner. However, performing services by the agent makes larger the object face to $\$ 383 \mathrm{HGB}$ or Article 1711 from the Italian Civil Code which limits the activity of the agent only to purchasing or selling of goods.

In comparison to the Italian regulation of the commission, the regulation offered by the new Romanian Civil Code is ampler, the rules on mandatory instructions of the principal and on the compensation of the agent being particularly relevant.

Therefore, although the agent is required to strictly observe the express instructions received from the principal, Article 2048, paragraph 2 allows distancing from the instructions only if the following cumulative requirements are complied :

20 Compare Article 1984 from the French Code which states that "le mandat ou procuration est un acte par lequel une personne donne à une autre le pouvoir de faire quelque chose pour le mandant et en son nom".

21 See in Italian doctrine MINERVINI, Gustavo. Il mandato, la commissione, la spedizione. Turin: UTET, 1952, p. 11. 
1. there is no time to obtain prior authorisation with reference to the nature of business;

2. it can reasonably be expected that the principal, knowing the altered circumstances, would have given the authorisation; and

3. distancing from the instructions does not fundamentally change the nature and purpose or the economic conditions of the received empowerment.

Per a contrario, any operation of the agent, in violation of or exceeding the powers received, devolves to himself, if not ratified by the principal, the agent being also obliged to pay damages.

Regarding the payment of agent fee, this cannot be rejected when the third party carries out precisely the contract concluded by the agent in compliance with the received empowerment (Article 2049 para. 1 NCC). Furthermore, unless provided otherwise, the fee is due when the third party does not perform its duty or claims the breach of contract exception (Article 2049 para. 2 NCC). If the authority for the sale of a building was given exclusively to an agent, the fee is due by the principal even if the sale was made directly by him or through a third party (Article 2049 para. 3 NCC).

If the principal revokes the power given to the agent until the execution of the document with the third party, the agent is entitled to a part of the fee, which is determined by taking into account his implication and expenditure in order to fulfil his engagement (Article 2051 NCC, which reproduces Article 1734 from the Italian Civil Code).

\section{Agency agreement}

By transposing the provisions of Directive 86/653/EEC, the code regulated the agency agreement as an autonomous figure (Article 2072 NCC) which was added to the major forms of representation mentioned above.

Some remarks are needed even prima facie the Code would retain the text of the Directive. For example, if Article 1 of the Directive retains as agreement object the negotiation in order to sale or purchase of products, the regulation of the Code is broader. The principal may empower the agent to negotiate or to negotiate and conclude agreements on account of and on behalf of the principal, for a consideration (Article 2072 para. 1 NCC) ${ }^{22}$.

The agent's activity will take place in one or more regions determined by contract.

Article 2072, paragraph 2 states, to the purpose pursued by the Directive, that the agent is an independent operator acting with a professional title, without being the employee in charge of the principal at the same time.

22 See art.1742 from the Italian Civil Code and $\$ 84$ HGB. 
The key feature of the agency agreement is that of promoting the principal's products or services on agent's market.

According to the Article 2074, paragraph 1 NCC the agent cannot negotiate or conclude on his own behalf, without the consent of the principal, in the region determined by the agency contract, contracts for goods and services similar to those covered by agency agreement.

However, in the absence of a contrary contractual provision, the agent can represent several principals and the principal can conclude contracts with several agents in the same region and for the same type of contracts (Article 2074, para. 2 NCC); the representation by the agent of several principals competing for the same region and same type of contracts can be achieved only under an express provision to this effect. The sense is relatively different from the Italian regulation (Article 1743 - Diritto di esclusiva) which denies that option.

In order to transpose the Directive 86/653/EEC, Article 2075, paragraph 1 NCC retains by non-compete clause that contractual stipulation whose effect is to restrict the professional activity of the agent during the agency contract or after its termination.

For the purposes pursued by the Directive, the non-compete pact, valid only in writing, will apply exclusively to the geographical region or to the group of people and geographical area covered by the agency contract, and only for goods and services the agent is authorised to negotiate on and, as far as the period is concerned, will not have effect for more than two years after termination of the agency contract (Article 2075, para. 2-5 NCC).

Regarding the agent's obligations, Article 2079 NCC states that the latter must fulfil, in person or by his employees, the obligations assumed, in good faith and loyalty, to procure for and communicate the principal the information which may be of interest regarding the regions agreed by the parties, to negotiate and, if possible, to conclude the contracts for which he is empowered, under the most favourable conditions for the principal, and to comply with reasonable instructions received from the principal.

In addition to the rules imposed by EU Directive (Article 3 para.2), the Romanian regulation requires keeping a separate record for contracts that relate to each principal and storage of goods or samples in a way that ensures their identification (Article 2079 NCC).

In relation to the principal's obligations, in conformity with the Article 4 of the Directive, the Romanian regulation states that he is obliged to provide the agent, in time and in appropriate amounts, samples, catalogues, tariffs and any other documentation necessary to the agent for the execution of his empowerment, to provide the agent with the information necessary for execution of the agency contract, to give notice to the agent, in a reasonable time, when he 
anticipates the contracts' value will be significantly lower than that to which the agent would normally have expected and to pay the agent remuneration under the conditions and within the time specified in the contract or provided by law (Article 2080 para. 1 NCC).

Also, the principal must notify the agent, within a reasonable time, upon the acceptance, refusal or failure of a negotiated agreement or, where appropriate, concluded by the agent (Article 2080 para. 2 NCC).

Some problems of interpretation may emerge in the sphere of agent's right to remuneration.

The ground for that remuneration would be according to the Article 2082, paragraph 1 NCC the agreements concluded as a result of his intervention.

Because the text is different from the Article 6 of the Directive, the formulation is criticisable.

As we have just analysed, the goal of the contract is to negociate or to negociate and conclude various contracts on account of and behalf of the principal (Article 2072 NCC). The agent has to negociate and to do all his best to conclude, but he has to be paid for all his work even when he has not reached the commercial target desired by the principal.

Therefore, while Article 2082 paragraph 1 NCC obviously conditions the remuneration on the number or value of contracts concluded through the agent the Article 2072 NCC considers remuneration as consideration even for the negotiation of the contract.

From this point of view, it is possible that Article 2082 paragraph 1 NCC contravenes the EU Directive.

Obviously, the remuneration may be expressed in fixed or variable amounts, in relation to the number of trade agreements or documents, or their value, when it is called commission.

Transposing the Article 7 para. 1 of the Directive, the Civil Code states that the agent is entitled to commission on contracts concluded during the agency contract, if they are concluded:

1. following his intervention;

2. without the agent's intervention, but with a customer previously acquired for similar trade agreements or documents (Article 2083 NCC).

Transposing the Article 7 paragraph 2 of the Directive the agent is entitled to commission when the contract is concluded with a customer from a specific region or a group of specific persons for whom the agent has received exclusive authorisation. 
In accordance with the Article 7 paragraph 2 of the Directive, the Civil Code states that the agent is entitled to commission for a contract concluded subsequently to the termination of the agency contract, if this agreement was mainly concluded thanks to the agent during the agency contract and the conclusion took place within a reasonable time after the termination of the agency contract, or when the order issued by the third party was received by the principal or agent before the termination of the agency contract, in the cases regulated by Article 2083 NCC.

Finally, according to the Article 2089 NCC, indefinite period agency agreement may be terminated unilaterally by either party, with a previous notice and when concluded for a definite period only if there is a specific clause on early unilateral termination.

In the first year of agreement the notice period must be at least one month.

If the contract duration is higher than one year, the minimum period of notice is increased by one month for each additional year that has begun, without notice period exceeding six months. If the parties agree on longer notice periods in the agency contract, there cannot be established longer notice periods for the agent task than those for the principal. If the parties do not agree otherwise, the notice period expires at the end of a calendar month.

Upon termination of the agency contract, the agent is entitled to receive compensation from the principal if the agent has acquired new customers for the principal or has significantly increased the volume of operations with existing customers, and the principal still gets substantial benefits from the transactions with these customers or the payment of this indemnity is equitable, having regard to the actual circumstances, especially the commissions that the agent should have received from transactions concluded with customers drawn by the principal and the possible confinement of the professional activity of the agent because of the existence in the agency contract of a non-compete clause (Article 2091 para.1 NCC).The indemnity may not exceed an amount equivalent to the annual remuneration calculated on the average annual pay received by the agent during the last 5-year contract. If the period does not amount to five years, the annual remuneration is calculated on the average received during that period (Article 2091 para.2 NCC). Granting this indemnity shall not prejudice the right of the agent to claim compensation under the law (Article 2091 para.3 NCC).

\section{General Conclusions}

Modernisation of the Romanian private law is an initiative that can only be welcomed. However, some general remarks are needed.

Despite the authors' intention to unify the Romanian private law some choices were not the best. E.g. the regulation of the mandate proves that even 
in the frame of a "unified" code there are rules applied to agreements concluded between natural persons and special rules applied when one of the parties is a "professional", a company. That demonstrate the unification was a failure because the special rules and the commercial agreement regulation was just moved from the former Commercial Code to the actual Civil Code.

Sometimes, the desire of modernisation erroneously implies the tendency to assimilate institutions from different legal systems, to take as much as possible from several national experiences.

We believe that adopting a national experience, as the main reference model, as close as possible to the interpretations given in the old jurisprudence under the repealed Civil Code would have been a more practical solution than creating a Civil Code influenced by the structure of the Napoleonic Code, by the modern institutions of the Italian Civil Code, of the Swiss Code or even the Civil Code of Québec.

\section{List of references}

BALDI, Roberto, VENEZIA, Alberto. Il contratto di agenzia: la concessione di vendita, il franchising. Milan : Giuffrè, 2008

BIANCA, Massimo. La vendita e la permuta. Turin: UTET, 1993

COTTINO, Gastone. Del contratto estimatorio e della somministrazione. Bologna : Zanichelli, 1970

DELEBECQUE, Philippe, BINCTIN Nicolas, ANDREU, Lionel. Opérations bancaires et Contrats commerciaux. Paris: LGDJ, 2018

DUMITRESCU, M.A. Manual de drept commercial. Bucharest: Alcalay, 1924

ECKERT, Hans Werner, MAIFELD, Jan, MATTHIESSEN, Michael. Handbuch des Kaufrechts. Munchen: CH Beck, 2007

ENDERLEIN, Fritz, MASKOW, Dietrich. International Sales Law: United Nations Convention on Contracts for the International Sale of Goods: Convention on the Limitation Period in the International Sale of Goods. New York: Oceana, 1992

MINERVINI, Gustavo. Il mandato, la commissione, la spedizione. Turin: UTET, 1952

SCHLECHTRIEM, Peter, BUTLER, Petra. UN Law on International Sales: The UN Convention on the International Sale of Goods. Berlin and Heidelberg: Springer, 2009

VELICU, Dan. Il progetto di codice civile rumeno con particolare riferimento ai contratti. I Contratti, 2007, vol. 15 no.4. 